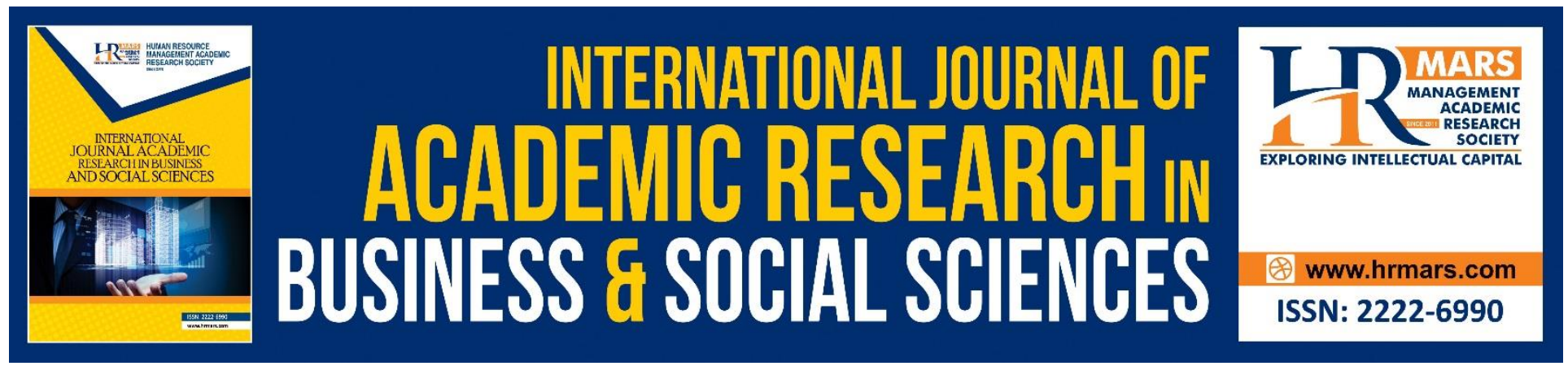

\title{
A Review of Life Cycle Assessment as Powerful Entrepreneurial Decision Maker Tools in Biotechnology Industry
}

Chee Loong Teo, Huam Hon Tat

To Link this Article: http://dx.doi.org/10.6007/IJARBSS/v8-i12/5410

DOI: $10.6007 /$ IJARBSS/v8-i12/5410

Received: 27 Nov 2018, Revised: 15 Dec 2018, Accepted: 26 Dec 2018

Published Online: 02 Jan 2019

In-Text Citation: (Teo \& Tat, 2018)

To Cite this Article: Teo, C. L., \& Tat, H. H. (2018). A Review of Life Cycle Assessment as Powerful Entrepreneurial Decision Maker Tools in Biotechnology Industry. International Journal of Academic Research in Business and Social Sciences, 8(12), 2109-2120.

\section{Copyright: (C) 2018 The Author(s)}

Published by Human Resource Management Academic Research Society (www.hrmars.com)

This article is published under the Creative Commons Attribution (CC BY 4.0) license. Anyone may reproduce, distribute, translate and create derivative works of this article (for both commercial and non-commercial purposes), subject to full attribution to the original publication and authors. The full terms of this license may be seen

at: http://creativecommons.org/licences/by/4.0/legalcode

Vol. 8, No. 12, 2018, Pg. 2109 - 2120

http://hrmars.com/index.php/pages/detail/IJARBSS

JOURNAL HOMEPAGE

Full Terms \& Conditions of access and use can be found at http://hrmars.com/index.php/pages/detail/publication-ethics 


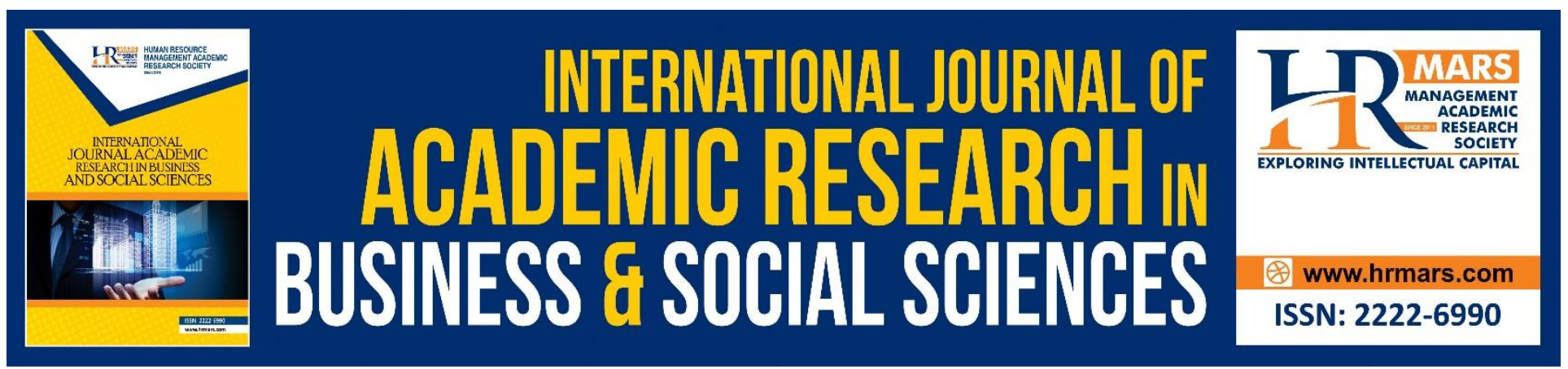

\title{
A Review of Life Cycle Assessment as Powerful Entrepreneurial Decision Maker Tools in Biotechnology Industry
}

\author{
Chee Loong Teo ${ }^{1,2}$ \\ ${ }^{1}$ Southern University College, Faculty of Business and Management, Jalan Selatan Utama, Off Jalan \\ Skudai, 81300 Skudai, Johor, Malaysia. \\ ${ }^{2}$ Diamond Star Biotechnology Sdn. Bhd., 85, Jalan Serampang, Taman Sri Tebrau, 80050, Johor \\ Bahru, Johor, Malaysia. \\ Huam Hon Tat ${ }^{3}$ \\ ${ }^{3}$ Putra Business School, 43400 UPM Serdang, Selangor Darul Ehsan, Malaysia.
}

\begin{abstract}
Life Cycle Assessment (LCA) is an organized and objective methodology for determining potential impacts and environment aspects related with service or product. Besides determining potential environment impacts, LCA potentially becomes a powerful decision maker tools to entrepreneur in industry. Nowadays, biotechnology industry consider as high potential, high risk and high return industry $(3 \mathrm{H})$, so that entrepreneurs in biotechnology need a very powerful, systematic, data based tool during decision making. In this review, the discussion focused on the introduction of LCA, the potential as decision maker and the beneficial potential of LCA in biotechnology industry and environment aspects.
\end{abstract}

Keywords: Life Cycle Assessment, Decision Maker Tool, Entrepreneurial, Industry, Biotechnology.

\section{Introduction}

In the whole world, Life Cycle Assessment becoming a famous and common tool for pharmaceutical and chemical industries to take on sustainability practices in industry operations (De Soete et al., 2014; Ott et al., 2016; Domènech et al., 2002). In addition, bio-based and petrol-based chemical as well as solvents has positioned LCA itself as a valuable tool to study the environmental performances (Khoo et al., 2016; Isoni et al., 2016; Adom et al., 2014; Righi et al., 2011). Life Cycle Assessment (LCA) is the assessment of social and environmental impacts of a service or a product throughout their whole life cycle, from the raw materials extraction until the life waste management end (Baumann and Tillman, 2004; Klopffer, 1997). 
Biotechnology industries begin in the 1970s with main purpose increasing the human life quality. Biotechnology industries differ from other science industries or conventional industry in that they use natural ingredients instead of artificial ones such as plant, cell and microorganism. However, the biotechnology Industry still consider highly volatile, unpredictable, high risk and high return industry due to the scientifically intensive operation of firms that reside here (http://www.valueline.com/Stocks/Industries/Industry_Overview_Biotechnology.aspx\#.W-OleJoQ2w).

Since the Life Cycle Assessment potential as decision maker tool and biotechnology industries growth rate keep increasing with $3 \mathrm{H}$ (high risk, high return and high potential), this tool and this field potential able to complementary to each other. However the lack of review discuss about Life Cycle Assessment as decision maker tool in industry. Thus in this study an attempt was made to discuss about as entrepreneurial decision maker tool in biotechnology industry.

\section{Biotechnology Industry}

Among the biotechnology industries, the new discoveries for the diseases treatment keep provide opportunities for growth and gains in stockholder value with high level of tolerant and unwanted results in short term. However, a patented biotechnology drugs will enjoy a 12 years period of protection from competitor and high sustainable period of high returns (http://www.valueline.com/Stocks/Industries/Industry_Overview_Biotechnology.aspx\#.W-OleJoQ2w).

With high profit and high potential reason, biotechnology industries become the major source of technological progress in agriculture and its will bring huge impact in industry production and leading to increase the productivity potential of animals and plants parallel reduce the losing in production attributable to pest and disease attack (Buckwell and Moxet, 1990).

Since $21^{\text {st }}$ century, the genetic modified crops also become an important success of the bioeconomy (Chapotin and Wolt, 2007). In 2014, more than eighteen million farmers in twenty eight countries planted genetic modified crop in 181.8 million hectares (ISAAA, 2014). The attractive benefit of genetic modified food such as $22 \%$ higher crop yields, $37 \%$ lower chemical pesticide usage and sixty eight percent higher profitability. In addition, the output had increased by USD 133.3 in 1996- 2013 (ISAAA, 2014) via enhanced cost effectiveness (Randhawa et al., 2014), which are believed the important factors for transitioning to bioeconomy or biotechnology industries. As mentioned, drug production via biotechnology industry also called biopharmaceuticals a crucial and fast growing biotechnology industry (Staub et al., 2011). In detail, biopharmaceuticals include innovative medicine that increase a healthier and longer life and treat the human diseases (Rathore et al., 2015). However, in this biotechnology industry needs a very huge capital investments and it stimulates innovation for the reducing costing and commercial and large scale (Lopes, 2015; Werner, 2004). In India, China, Brazil, Russia and South African, developing countries need worldwide cooperation to build up an innovative biotechnology drug industry that can struggle with developed countries in the world and 
INTERNATIONAL JOURNAL OF ACADEMIC RESEARCH IN BUSINESS AND SOCIAL SCIENCES

Vol. 8, No. 12, Dec, 2018, E-ISSN: 2222-6990 @ 2018 HRMARS

create novel economic growth to them (Rezaie et al., 2012). Besides, Asian countries such as Korea, Taiwan and Singapore have identified the biotechnology drug manufacturing as a potential tactical industry for economic growth twenty-one century (Hsieh and ofgren, 2009).

Accroding OECD report, bioplastics is the fastest rising industry in biotechnology field (OECD, 2013), shows potential alternative to petroleum-based plastics (Rohrbrek et al., 2013) and attracting global investors and governments' attention (Morone et al., 2015). The market for bioplastics may reach six point seventy three million tons in 2018 , the continents with the major capacity for bioplastics production will Asia region around $75.8 \%$, and then followed by South America region around $12.2 \%$ and Europe region around $7.6 \%$. Due the level awareness increasing, the biodegradable bioplastics production capacity will keep growing and the bio- polyhydroxyalkanoates and bio-polyactic acid will lead the trend (European BioPlastics, 2014).

According Dev S. report stated that, the biotechnology based industry will contribute to the huge potential economic development and transition toward the biotechnology industry for Asia especially to developing countries. Asia region countries are playing crucial roles in the biotechnology development, bio-refinery and bio-industry for the bio-based green economy and clean future, which is crucial factor it is because Asia contribute half of the global population and some developing countries are benefiting from huge number of biotechnology researchers (Dey S, 2014).

Table 1: Bio-industries out value estimation (Duu, 2016)

\begin{tabular}{|l|r|r|r|r|r|r|}
\hline & \multicolumn{1}{|c|}{ China } & \multicolumn{1}{c|}{ India } & \multicolumn{1}{c|}{ Japan } & \multicolumn{1}{c|}{ Korea } & Malaysia & \multicolumn{1}{c|}{ Taiwan } \\
\hline $\begin{array}{l}\text { Production value } \\
\text { of chemical } \\
\text { industry }\end{array}$ & 701730.00 & 116437.34 & 395020.81 & 158124.41 & 37673.25 & 74480.48 \\
\hline $\begin{array}{l}\text { Bioplastic } \\
\text { production value }\end{array}$ & 539.14 & 93.15 & 169.80 & 150.31 & 31.40 & 71.53 \\
\hline $\begin{array}{l}\text { Biophamarceutic } \\
\text { al production } \\
\text { value }\end{array}$ & 2271.55 & 3195.44 & 14782.49 & 1978.94 & 270.83 & 360.36 \\
\hline $\begin{array}{l}\text { Biohydrogen } \\
\text { production value }\end{array}$ & 100.49 & 16.67 & 56.57 & 22.64 & 5.39 & 10.67 \\
\hline $\begin{array}{l}\text { Other chemical } \\
\text { industry } \\
\text { production }\end{array}$ & 698818.82 & 113132.03 & 380011.95 & 155972.50 & 37365.62 & 74037.93 \\
\hline $\begin{array}{l}\text { Production value } \\
\text { of crops industry }\end{array}$ & 276890.84 & 131107.79 & 42158.16 & 19393.29 & 9733.30 & 6835.042 \\
\hline $\begin{array}{l}\text { GM crop } \\
\text { production }\end{array}$ & 8104.12 & 8014.58 & 42.16 & 19.39 & 9.73 & 6.84 \\
\hline $\begin{array}{l}\text { Other crops } \\
\text { production }\end{array}$ & 268786.72 & 123093.21 & 42116.00 & 19373.90 & 9723.57 & 6828.21 \\
\hline
\end{tabular}


INTERNATIONAL JOURNAL OF ACADEMIC RESEARCH IN BUSINESS AND SOCIAL SCIENCES

Vol. 8, No. 12, Dec, 2018, E-ISSN: 2222-6990 @ 2018 HRMARS

\begin{tabular}{|c|c|c|c|c|c|c|}
\hline $\begin{array}{l}\text { Plastic industry } \\
\text { share of chemical } \\
\text { industry }\end{array}$ & $\begin{array}{r}19.20751 \\
\%\end{array}$ & $20.00 \%$ & $\begin{array}{r}10.746296 \\
\%\end{array}$ & $\begin{array}{r}23.76527 \\
\%\end{array}$ & $\begin{array}{r}20.83961 \\
\%\end{array}$ & $24.0098 \%$ \\
\hline $\begin{array}{l}\text { Bioplastic } \\
\text { industry of plastic } \\
\text { industry }\end{array}$ & $0.4 \%$ & $0.4 \%$ & $0.4 \%$ & $0.4 \%$ & $0.4 \%$ & $0.4 \%$ \\
\hline $\begin{array}{l}\text { Pharmaceutical } \\
\text { industry share of } \\
\text { chemical industry }\end{array}$ & $\begin{array}{r}2.158050 \\
\%\end{array}$ & $\begin{array}{r}18.295652 \\
\%\end{array}$ & $\begin{array}{r}24.948032 \\
\%\end{array}$ & $\begin{array}{r}8.343409 \\
\%\end{array}$ & $\begin{array}{r}4.792663 \\
\%\end{array}$ & $3.2255 \%$ \\
\hline $\begin{array}{l}\text { Biopharmaceutic } \\
\text { al industry of } \\
\text { pharmaceutical } \\
\text { industry }\end{array}$ & $15 \%$ & $15 \%$ & $15 \%$ & $15 \%$ & $15 \%$ & $15 \%$ \\
\hline $\begin{array}{l}\text { Hydrogen } \\
\text { industry of } \\
\text { chemical industry }\end{array}$ & $\begin{array}{r}0.286395 \\
\%\end{array}$ & $0.286395 \%$ & $0.286395 \%$ & $\begin{array}{r}0.286395 \\
\%\end{array}$ & $\begin{array}{r}0.286395 \\
\%\end{array}$ & $\begin{array}{r}0.286395 \\
\%\end{array}$ \\
\hline $\begin{array}{l}\text { Biohydrogen } \\
\text { industry of } \\
\text { hydrogen } \\
\text { industry }\end{array}$ & $5 \%$ & $5 \%$ & $5 \%$ & $5 \%$ & $5 \%$ & $5 \%$ \\
\hline $\begin{array}{l}\text { GM crop shares } \\
\text { of crop industry }\end{array}$ & $\begin{array}{r}2.926829 \\
\%\end{array}$ & $6.112972 \%$ & $0.1 \%$ & $0.1 \%$ & $0.1 \%$ & $0.1 \%$ \\
\hline
\end{tabular}

Table 1 showed that bio-industries out values estimation (Millions USA, \%) for China,Japan, India, Korea, Taiwan and Malaysia (Duu, 2016) in production value of chemical industry (Bioplastic production value, biopharmaceutical production value, biohydrogen production value and other chemical industry production) and production value of crops industry (geneticmodified crop production and other crops production) (Duu, 2016). 
INTERNATIONAL JOURNAL OF ACADEMIC RESEARCH IN BUSINESS AND SOCIAL SCIENCES

Vol. 8, No. 12, Dec, 2018, E-ISSN: 2222-6990 @ 2018 HRMARS

Table 2: The levels and growth rate economic growth to bio-industry (Duu, 2016)

\begin{tabular}{|c|c|c|c|c|c|c|c|}
\hline & & \multicolumn{2}{|c|}{$\begin{array}{l}\text { Baseline (bio-industry } \\
\text { cost down } 3 \% \text { ) }\end{array}$} & \multicolumn{2}{|c|}{$\begin{array}{c}\text { Scenario II (bio-industry } \\
\text { cost down } 20 \% \text { ) }\end{array}$} & \multirow{2}{*}{\multicolumn{2}{|c|}{$\begin{array}{c}\text { Differences } \\
\text { between scenario II } \\
\text { and scenario I }\end{array}$}} \\
\hline & $\begin{array}{l}\text { Base- year } \\
\text { real GDP }\end{array}$ & Real GDP & $\begin{array}{c}\text { Geometri } \\
\text { c annual } \\
\text { growth } \\
\text { rate }\end{array}$ & Real GDP & $\begin{array}{c}\text { Geometri } \\
\text { c annual } \\
\text { growth } \\
\text { rate }\end{array}$ & & \\
\hline & 2007 & 2050 (C) & $\begin{array}{c}\text { 2014- } 50 \\
\text { (A) }\end{array}$ & 2050 (D) & $\begin{array}{c}\text { 2014- } 50 \\
\text { (B) }\end{array}$ & $\begin{array}{l}\text { Levels } \\
\text { (D-C) }\end{array}$ & $\%(B-A)$ \\
\hline China & $3,701,129$ & $30,103,186$ & $4.36 \%$ & $30,236,094$ & $4.38 \%$ & 132,907 & $\begin{array}{r}0.0124 \\
\%\end{array}$ \\
\hline India & $1,232,817$ & $12,026,576$ & $5.27 \%$ & $12,109,126$ & $5.29 \%$ & 82,550 & $\begin{array}{r}0.0195 \\
\%\end{array}$ \\
\hline Japan & $4,377,945$ & $6,525,025$ & $1.08 \%$ & $6,611,203$ & $1.11 \%$ & 86,178 & $\begin{array}{r}0.0358 \\
\% \\
\end{array}$ \\
\hline Korea & $1,049,236$ & $3,448,586$ & $2.75 \%$ & $3,446,416$ & $2.75 \%$ & $-2,170$ & $\begin{array}{r}- \\
0.0017 \\
\%\end{array}$ \\
\hline $\begin{array}{l}\text { Malaysi } \\
\text { a }\end{array}$ & 186,642 & $1,174,884$ & $4.37 \%$ & $1,220,396$ & $4.48 \%$ & 45,512 & $\begin{array}{r}0.1073 \\
\% \\
\end{array}$ \\
\hline Taiwan & 393,763 & $1,240,716$ & $2.68 \%$ & $1,251,210$ & $2.71 \%$ & 10,494 & $\begin{array}{r}0.0234 \\
\% \\
\end{array}$ \\
\hline $\begin{array}{l}\text { Rest of } \\
\text { World }\end{array}$ & $\begin{array}{r}44,889,81 \\
6 \\
\end{array}$ & $\begin{array}{r}117,965,20 \\
6 \\
\end{array}$ & $2.33 \%$ & $\begin{array}{r}119,216,18 \\
4\end{array}$ & $2.36 \%$ & $\begin{array}{r}1,250,97 \\
8 \\
\end{array}$ & $\begin{array}{r}0.0292 \\
\% \\
\end{array}$ \\
\hline World & $\begin{array}{r}55,831,34 \\
7\end{array}$ & $\begin{array}{r}172,484,17 \\
9 \\
\end{array}$ & $2.69 \%$ & $\begin{array}{r}174,090,62 \\
9\end{array}$ & $2.72 \%$ & $\begin{array}{r}1,606,45 \\
0\end{array}$ & $\begin{array}{r}0.0257 \\
\%\end{array}$ \\
\hline
\end{tabular}

Table 2 showed that levels and growth rate of economic growth for China, Japan, India, Korea, Taiwan, Malaysia, rest of world and word (Duu, 2016).

\section{Biotechnology Industry in Malaysia}

According Mohd and Wan 2009 reported that huge potential for environment and industrial biotechnology in Malaysia. The National Biotechnology Policy was started in 2015, with the focus "biotechnology for wealth creation and social well-being." The government policy identified industrial biotechnology as one of the 3 main focuses. Since the Malaysian Biotechnology Corporation has spear headed the government's initiative for the biotechnology growth in Malaysia. The Malaysia biotechnology road map consists of 3 stages: First Phase (2005-2010) focus on capacity building, Second Phase (2011-2015) focus on science to business and Third Phase (2016-2020) focus on global presence. Up to date, the Malaysian Biotechnology Corporation has linked more than one hundred companies under Bionexus programme (Biotechnology Status Company is Malaysia) which 30 companies have investments from United States America, France, Britain, German, Belgium, Italy, India, China, Japan, Hong Kong, Thailand, Australia, Singapore, New Zealand and Taiwan. In addition, 
Malaysia government had allocated US\$ 65 million to support the building biotechnology business. Malaysia biotechnology industry is values around US\$ three hundred seventy million and targeted growing rate around $22 \%$ annually (Mohd and Wan, 2009).

\section{Life Cycle Assessment (LCA)}

Life Cycle Assessment (LCA) consider as organized and objective methodology for determining potential impacts and environment aspects related with service or product. LCA consist of 4 phases: first phase (the Scope Definition), second phase (the Life Cycle Inventory Assessment), third phase (the Life Cycle Impact Assessment) and the last phase (Interpretation). The Scope Definition consists of the functional unit, establishing the goal, the life cycle stages and the system boundaries; all parameters depend on the intended use and subject of the study. While, the Life Cycle Inventory phase consists in considering the output or input data of the system under study. In the Life Cycle Impact Assessment phase, impact categories are gained using the life cycle inventory results; the calculation of impact categories' number/ magnitude needs the use of references information. Lastly, in the interpretation phase, the data are analyzed; it includes the explanation of the limitation, a series of recommendations and a conclusion (ISO, 2006).

\section{Life Cycle Assessment as Decision Maker Tools in Industry}

In the industries, LCA has been popular used for the improvement of the environmental performance of the services and goods, amongst which goods belonging to the agricultural food sector. Some of the international scientific literatures consider simplifications of Life Cycle Assessment a related approach in order to make Life Cycle Assessment easier to apply and use, especially for small and medium sized enterprises called SMEs, which normally lack in resources. Despite a protracted theoretical discussion to the simplification of Life Cycle Assessment, some simplification approaches and the tools have been developed and proposed in the last decades in agricultural food sector. In the below figure 1, 2,3 and 4 showed lemon juice,roasted coffee, olive oil and wine's Life Cycle Assessment model (loannis et al., 2017). 
INTERNATIONAL JOURNAL OF ACADEMIC RESEARCH IN BUSINESS AND SOCIAL SCIENCES Vol. 8, No. 12, Dec, 2018, E-ISSN: 2222-6990 @ 2018 HRMARS

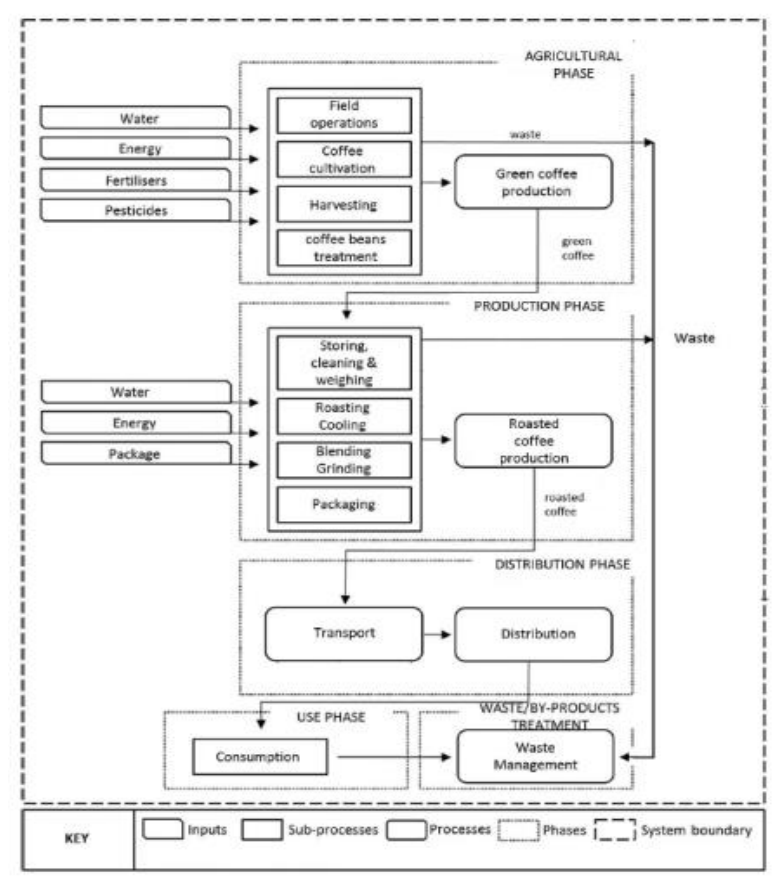

Figure 1 The LCA for roasted coffee production (loannis et al., 2017).

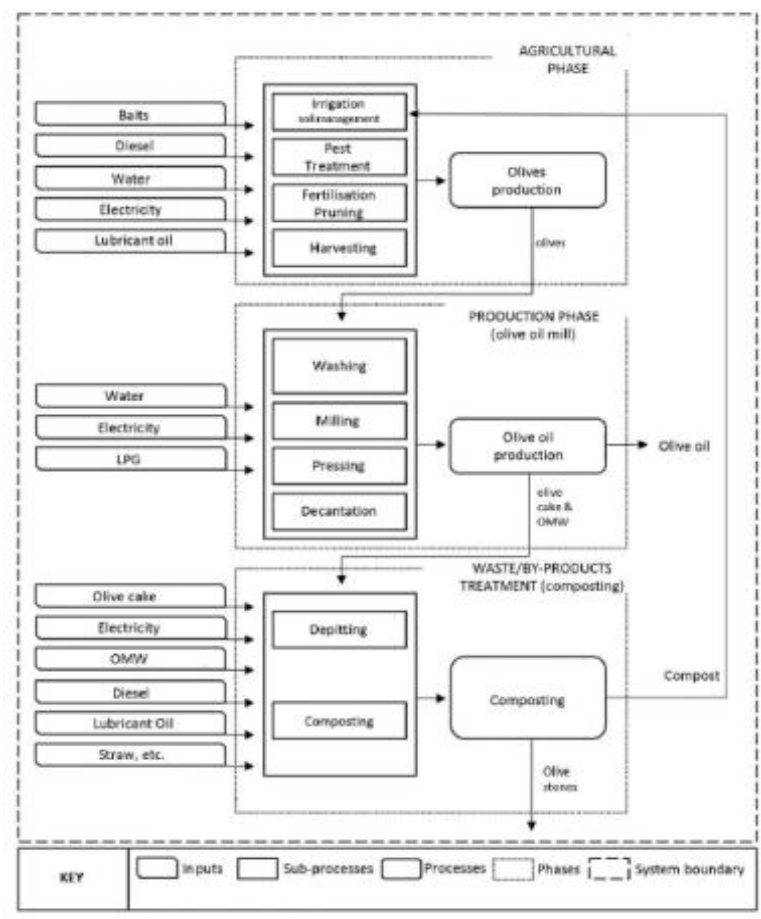

Figure 3 The LCA for olive oil production (loannis et al., 2017).

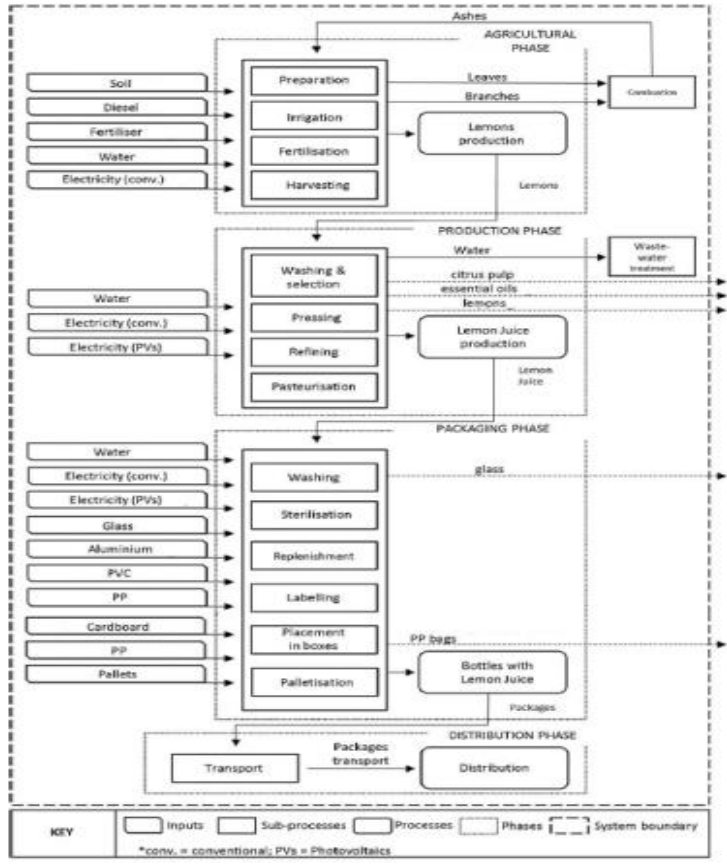

Figure 2 The LCA for lemon juice production (loannis et al., 2017).

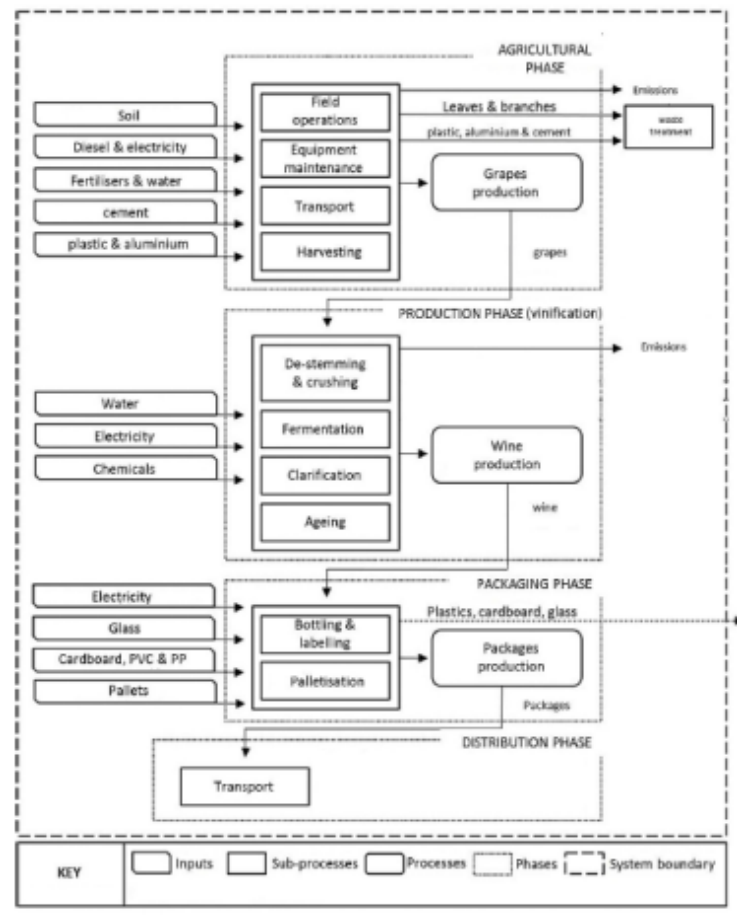

Figure 4 The LCA for red wine production (loannis et al., 2017). 
According the Simboli et al. (2015) report stated that the level of importance has been increasing of Life Cycle Assessment as a tool to support decision-making in small sized companies and manufacturing typed companies (Simboli et al., 2015).

In cooperative small and medium enterprise networks, the Life Cycle Assessment can be used to implement green marketing and eco-design (Nakano and Hirao, 2011). According Lozano (2015) report stated that collaborative approaches can assist small and medium enterprises build more sustainable and stronger strategies. Networks among small and medium enterprises and institutions also can be useful in supporting the application of Life Cycle Assessments in industrial clusters (Zanghelini et al., 2016). Collaboration is thus not confined to the supply chain but also includes regulators, non-traditional members, members of the community and competitors. (Hoof and Thiell, 2014). Singh et al. (2007) also stated that used a Life Cycle Assessment to identify the best design of an eco-industrial park.

\section{Conclusion}

This paper discusses the potential of Life Cycle Assessment as decision maker tool can be imposed and implement in high potential and high risk biotechnology industry. Although this paper only provided short review regard the fundamental while it will be one of the practical references to sustainable the related industry.

\section{Corresponding Author}

Huam Hon Tat, Putra Business School, 43400 UPM Serdang, Selangor Darul Ehsan, Malaysia.

Email: huam@putrabs.edu.my

\section{References}

Adom, F., Dunn, J.B., Han, J., Sather, N., (2014). Life-cycle fossil energy consumption and greenhouse gas emissions of bioderived chemicals and their conventional counterparts. Environ. Sci. Technol. 48, 14624-14631.

Baumann H, Tillman A-M. (2004) The Hitch Hiker's guide to LCA.

Buckwell, A., Moxey, A. (1990). Biotechnology and agriculture.Food Policy, 15, 44-56.

Chapotin, Wolt. (2017). Genetically modified crops for the bioeconomy: meeting public and regulatory expectations. Transgenic Res, 16,675-688.

De Soete, W., Debaveye, S., De Meester, S., Van der Vorst, G., Aelterman, W., Heirman, B., Cappuyns, P., Dewulf, J., (2014). Environmental sustainability assessments of pharmaceuticals: an emerging need for simplification in life cycle assessments. Environ. Sci. Technol. 48, 12247-12255. 
INTERNATIONAL JOURNAL OF ACADEMIC RESEARCH IN BUSINESS AND SOCIAL SCIENCES

Vol. 8, No. 12, Dec, 2018, E-ISSN: $2222-6990$ C 2018 HRMARS

Dey, S. (2014). Asian bioeconomy and biobusiness: current scenario and future prospects. New Biotechnol, 31S-S34.

Domènech, X., Ayllón, J.A., Peral, J., Rieradevall, J., (2002). How green is a chemical reaction? Application of LCA to green chemistry.Env. Sci. Technol. 36, 5517-5520.

Duu, H. L. (2016). Bio-based economies in Asia: Economic analysis of development of bio-based industry in China, India, Japan, Korea, Malaysia and Taiwan. International journal of hydrogen energy, 41, 4333-4346.

European bioplastics (2014) https://www.european-bioplastics.org/press-release-archive-20152014/

Hsieh, C.R., Lofgren, H. (2009). Biopharmaceutical innovation and industrial development in South Korea, Singapore and Taiwan.Aust Health Rev, 33(2),245- 257.

International Standard Organization (ISO), (2006). Environmental Management - Life Cycle Assessment.ISO 14040/44.

International Service for the Acquisition of Agri-Biotech Application (ISAAA).(2014). Global status of commercialized biotech/GM Crops.

Ioannis, A., Roberta, S., Luigia, P.,Giovanni, M.,Andrea, R. (2017). Is there a simplified LCA tool suitable for the agri-food industry? An assessment of selected tools.Journal of Cleaner Production, 149, 406425.

Isoni, V., Wong, L.L., Khoo, H.H., Halim, I., Sharratt, P., (2016). Q-SAVESS: a methodology to help solvent selection for pharmaceutical manufacture at the early process development stage. Green Chem. 18, 6564-6572.

Khoo, H.H., Ee, W.L., Isoni, V., (2016). Bio-chemicals from lignocellulose feedstock: sustainability, LCA and the green conundrum. Green Chem. 18, 1912-1922.

Klöpffer W. (1997) Life cycle assessment: from the beginning to the current state. Environ SciPollut Res Int;4(4):223-8.

Lopes, A.G. (2015). Single-use in the biopharmaceutical industry: a review of current technology impact, challenges and limitations. Food Bioprod Process, 93:98-114.

Lozano, R. (2015). A holistic perspective on corporate sustainability drivers.Corp. Soc. Responsib. Environ. Manag, 22, 32-44. 
INTERNATIONAL JOURNAL OF ACADEMIC RESEARCH IN BUSINESS AND SOCIAL SCIENCES Vol. 8, No. 12, Dec, 2018, E-ISSN: $2222-6990$ C 2018 HRMARS

Mohd, A.H., Wan, A.R., Wan, Y. (2009). Current status of industrial biotechnology in Malaysia.

Morone, P., Tartiu, V.E., Falcone, P. (2015). Assessing the potential of biowaste for bioplastics production through social network analysis.J Clean Prod.90, 43- 54.

Nakano, K., Hirao, M. (2011). Collaborative activity with business partners for improvement of product environmental performance using LCA. J. Clean. Prod. 19, 1189- 1197.

OECD. (2013). Policies for bioplastics in the context of a bioeconomy.http://www.oecd.org/officialdocuments/publicdisplaydocumentpdf/?cote1/4DSTI/ STP/BIO

(2013)6/FINAL\&docLanguage $1 / 4$ En.

Ott, D., Borukhova, S., Hessel, V., (2016).Life cycle assessment of multi-step rufinamide synthesis from isolated reactions in batch to continuous microreactor networks. Green Chem. 18, 1096-1116.

Rathore, A.S., Gernaey, K.V., Calado, C.R.C., Yoon, S. (2015). Process analytical technologies in biopharmaceutical process development.J ChemTechnolBiotechnol.90,213-214.

Rezaie, R., McGahan, A.M., Frew, S.E., Daar, A.S., Singer, P.A. (2012).Emergence of biopharmaceutical innovators in China, India, Brazil, and South Africa as global competitors and collaborators. Health Res Policy Syst, 10:18.

Righi, S., Morfino, A., Galletti, P., Samori, C., Tugnol, A., Stramigioli, C., (2011).Comparative cradle-togate life cycle assessments of cellulose dissolution with 1-butyl-3-methylimidazolium chloride and $\mathrm{N}$ methyl-morpholine-N-oxide. Green Chem. 13, 367-375.

Rohrbeck, M., Korsten, S., Fischer, C.B., Wehner, S., Kessler, B. (2013). Diamond-like carbon coating of a pure bioplastic foil. Thin Solid Films, 545,558-563.

Simboli, A., Raggi, A., Rosica, P. (2015). Life cycle assessment of process eco- innovations in an SME automotive supply network. Sustainability, 7, 13761-13776.

Singh, A., Lou, H.H., Yaws, C., Hopper, L., Pike, R.W. (2007). Environmental impact assessment of different design schemes of an industrial ecosystem. Resour. Conser.Recycl. 51, 294-313.

Staub A., Guillarme D., Schappler J., Veuthey J. L., Rudaz S.(2011). Intact protein analysis in the biopharmaceuticalfield.J Pharmaceut.Biomed.Analysis 55: 810-822.

Werner, R.G. (2004). Economic aspects of commercial manufacture of biopharmaceuticals.J Biotechnol, 113,171-182. 
INTERNATIONAL JOURNAL OF ACADEMIC RESEARCH IN BUSINESS AND SOCIAL SCIENCES

Vol. 8, No. 12, Dec, 2018, E-ISSN: 2222-6990 @ 2018 HRMARS

Zanghelini, G. M., Cherubini, E., Orsi,P., Soares, S. R., (2014) Waste management Life Cycle Assessment: The case of a reciprocating air compressor in Brazil.Journal of Cleaner Production70:164-174. 